\title{
Оцінка виявлення фенотипічних маркерів недиференційованої дисплазії сполучної тканини у жінок при загрозі передчасних пологів
}

\author{
Т.В. Ібадова, В.В. Маляр, В.А. Маляр, Вол.В. Маляр \\ Державний вищий навчальний заклад «Ужгородський національний університет», Ужгород, Україна
}

\begin{abstract}
Анотація. Передчасні пологи, особливо на ранніх термінах вагітності, тісно пов'язані з перинатальною захворюваністю та смертністю. Мета: оцінити виявлення та клінічне значення маркерів недиференційованої дисплазії сполучної тканини у вагітних при загрозі передчасних пологів. Об'єкт і методи дослідження. Проведений клінічний аналіз фенотипічних ознак недиференційованої дисплазії сполучної тканини у 270 вагітних з одноплідною вагітністю при загрозі передчасних пологів, які виділені у дві репрезентативні групи: 1-ша ( $n=112$, основна) - 3 наявністю фенотипічних ознак недиференційованої дисплазії сполучної тканини та 2-га ( $\mathrm{n=158,}$ контрольна) - без фенотипічних ознак. Результати. Серед фенотипічних ознак недиференційованої дисплазії сполучної тканини у вагітних при загрозі передчасних пологів найчастіше виявляли астенічну будову тіла (38,4\%), гіпермобільність суглобів (33,9\%), міопію (31,3\%). Крім того, досить часто виявляли стигми дизембріогенезу: різноманітні аномалії скелету, опорно-рухового апарату, зубів. Виявлено також зниження індексу маси тіла, показників відношення окружності зап'ястка до довжини II пальця, розмаху рук до росту, рясні менструації. У 86,6\% пацієнток відмічали метеозалежність та суб'єктивні ознаки респіраторного синдрому. Висновок. Отримані результати дозволяють відносити вагітних з ознаками недиференційованої дисплазії сполучної тканини до групи високого ризику недоношування вагітності з розвитком геморагічних ускладнень.

Ключові слова: передчасні пологи, недиференційована дисплазія сполучної тканини, фенотипічні ознаки.
\end{abstract}

\section{Вступ}

Актуальність проблеми зумовлена значною поширеністю синдрому недиференційованої дисплазії сполучної тканини (НДСТ), частота якої в окремих популяціях сягає 26-80\% [1-3]. У генезі передчасного переривання вагітності істміко-цервікальна недостатність становить $36 \%$ [4, 5]. Клінічні прояви синдрому НДСТ, за даними літератури, виявляють вперше під час вагітності [6, 7].

Однак попри значну кількість наукових праць, присвячених проблемі акушерських і перинатальних ускладнень у жінок з НДСТ, питання передчасного переривання вагітності залиша$\epsilon$ ться далеким від вирішення. У зв'язку з цим доцільність подальшого вивчення цієї проблеми не викликає сумнівів.

Мета: виявити фенотипічні ознаки синдрому НДСТ у вагітних Закарпаття, встановити клінічні прояви.

\section{Об"єкт і методи дослідження}

У дослідження включено 270 вагітних з одноплідною матковою вагітністю та загрозою передчасних пологів терміном 22-36 тиж гестації, госпіталізованих у КП «Ужгородський міський пологовий будинок». В основну клінічну групу (1-шу) увійшли 112 пацієнток 3 фенотипічними маркерами НДСТ. Контрольну групу (2-гу) становили 158 пацієнток з відсутністю ознак НДСТ. Оцінку фенотипічних ознак НДСТ проводили за клінічними рекомендаціями [8]. Клінічний огляд вагітних проводили згідно з протоколом, антропометричні вимірювання здійснювали з акцентом на виявленні фенотипічних маркерів НДСТ.

Дослідження проводили при згоді пацієнтки з дотриманням конвенції про захист прав і гідності людини. Статистичну обробку проводили з використанням сучасних методів варіаційної статистики за допомогою стандартних програм статистичного аналізу «Microsoft Excel 7.0» та «Statistica for Windows 6.0».

\section{Результати та їх обговорення}

Обстежуванігрупи були репрезентативними завіком, соціальним

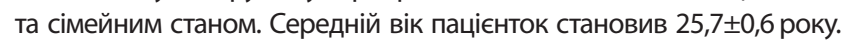
71,1\% вагітних мали вищу освіту, 18,1\% - середню, 9,6\% - студентки. На момент вагітності 30,7\% пацієнток не працювали. При аналізі анамнестичних даних у 1-й групі >50\% пацієнток висували скарги на виражений передменструальний синдром, альгодисменорею, метрорагію. Серед фенотопічних ознак НДСТ найчастіше виявляли астенічну будову тіла (38,4\%), гіпермобільність суглобів (33,9\%), міопію (31,3\%), лакунарний тип райдужної оболонки (28,6\%), виражену венулярну сітку (24,1\%), зниження індексу зап'ястка (24,1\%), блакитні склери (17,9\%), варикозне розширення вен нижніх кінцівок $(16,1 \%)$, варикозне розширення гемороїдальних вен (10,7\%), ознаку великого пальця (9,8\%), поздовжню плоскостопість $(9,8 \%)$, поперечну плоскостопість (3,6\%). У контрольній групі кількість випадків з патологією сполучної тканини була значно меншою (табл. 1).

Таблиця 1 Частота фенотипічних ознак дисплазії сполучної тканини у досліджуваних групах

\begin{tabular}{lcc}
\hline \multicolumn{1}{c}{ Фенотипічна ознака } & $\begin{array}{c}\text { 1-ша група } \\
\text { (n=112), } \mathbf{n}(\%)\end{array}$ & $\begin{array}{c}\text { 2-га група } \\
\text { (n=158), } \mathbf{n}(\%)\end{array}$ \\
\hline Астенічна будова тіла & $43(38,4 \%)$ & $3(1,9 \%)$ \\
\hline Гіпермобільність суглобів & $38(33,9 \%)$ & $3(1,9 \%)$ \\
\hline Міопія & $35(31,3 \%)$ & $5(3,2 \%)$ \\
\hline Лакунарний тип райдужної оболонки & $32(28,6 \%)$ & $3(1,9 \%)$ \\
\hline Виражена венулярна сітка & $27(24,1 \%)$ & $2(1,3 \%)$ \\
\hline Зниження індексу зап'ястка & $27(24,1 \%)$ & $2(1,3 \%)$ \\
\hline Блакитні склери & $20(17,9 \%)$ & $2(1,3 \%)$ \\
\hline Варикозне розширення вен нижніх кінцівок & $18(16,1 \%)$ & - \\
\hline Варикозне розширення гемороїдальних вен & $12(10,7 \%)$ & $1(0,6 \%)$ \\
\hline Ознака великого пальця & $11(9,8 \%)$ & - \\
\hline Поздовжня плоскостопість & $10(8,9 \%)$ & - \\
\hline Поперечна плоскостопість & $4(3,6 \%)$ & - \\
\hline
\end{tabular}

У вагітних з невиношуванням в анамнезі суттєво частіше, ніж у пацієнток контрольної групи, відмічали прояви дизембріогенезу: різноманітні аномалії скелету, опорно-рухового апарату, зубів, очей та патологію вен нижніх кінцівок і статевих органів, які вважають ознаками синдрому НДСТ. Крім того, на основі антропометричних досліджень у ранні терміни гестації у вагітних 1-ї групи встановлено зниження індексу маси тіла (IMT), відношення окружності зап'ястка до довжини II пальця, а також розмаху рук до росту (табл. 2). 
Таблиця 2 Антропометричні параметри (M $\pm \mathrm{m})$

\begin{tabular}{lcc}
\hline \multicolumn{1}{c}{ Параметр } & $\begin{array}{c}\text { 1-ша група } \\
(\mathbf{n = 1 1 2 ) ,} \mathbf{n}(\%)\end{array}$ & $\begin{array}{c}\text { 2-га група } \\
(\mathbf{n = 1 5 8 ) ,} \mathbf{n}(\%)\end{array}$ \\
\hline IMT, кг/M² & $60,5 \pm 0,6$ & $66,1 \pm 0,9$ \\
\hline Окружність зап'ястка/довжина II пальця & $2,4 \pm 0,2$ & $2,2 \pm 0,5$ \\
\hline Розмах рук/ріст & $0,987 \pm 0,006$ & $0,979 \pm 0,006$ \\
\hline
\end{tabular}

Геморагічний синдром в анамнезі був одним із типових проявів мезенхімальних дисплазій у вагітних 1-ї групи. Носові кровотечі і кровоточивість ясен відмічали у 73,2\%, рясні менструації - у 54,5\% паці$\epsilon$ нток. Легке утворення синців виявлено у $44,6 \%$, а також збільшення вираженості геморагічного синдрому в період вагітності $(p<0,05)$.

Одним із характерних клінічних проявів фенотипічного синдрому НДСТ $\epsilon$ респіраторний синдром, який суб'єктивно виявляється відчуттям нестачі повітря, бажанням періодично зробити глибокий вдих. Серед характерних клінічних ознак відмічали задишку при незначному фізичному та емоційному навантаженні або у стані спокою. У 1-й групі вагітних зареєстрована висока питома вага метеочутливості, а також непереносимість задушливих приміщень, яка відмічена у 86,6\% пацієнток $(\mathrm{p}<0,05)$.

Одним із провідних клінічних проявів був синдром судинних розладів, який виявлявся головним болем, запамороченням.

Нерідко у пацієнток 1-ї групи виникали порушення периферичного кровообігу і мікроциркуляції. Клінічно вони проявлялися блідістю, синюшністю або «мраморністю» шкіри долонь і ступнів, онімінням, але при цьому не відмічали трофічних порушень.

\section{Висновок}

Отримані результати дозволяють віднести вагітних з ознаками НДСТ до групи високого ризику недоношування вагітності з розвитком геморагічних ускладнень.

\section{Перспективи подальших наукових досліджень}

Розробка скринінгової програми для визначення фенотопічних ознак НДСТ вагітних та впровадження профілактично-лікувальних заходів, які знижуть ускладнення в період вагітності.

\section{Конфлікт інтересів}

Відсутній.

\section{Внесок кожного з авторів у підготовку статті}

В.В. Маляр, В.А. Маляр - концепція та дизайн дослідження; Т.В. Ібадова, Вол.В. Маляр - збір даних; Т.В. Ібадова, В.В. Маляр, В.А. Маляр, Вол.В. Маляр - аналіз та інтерпретація даних; Т.В. Ібадова - написання статті; В.В. Маляр - редагування статті; В.А. Маляр - остаточне затвердження статті.

\section{Список використаної літератури}

1. Гулиева 3.С., Герасимов А.М. (2013) Недифференцированная дисплазия соединительной ткани как фактор риска развития невынашивания беременности в ранние сроки. Вест. Иванов. мед. акад., 18(2): 39-40.

2. Омельченко Л.І., Ошлянська О.А., Скибан Г.В., Ніколаєнко В.Б. (2007) До питання про поширеність дисплазій сполучної тканини у дітей. Перинатол. педиатр., 3: 80-83.

\section{Відомості про авторів:}

Ібадова Тунзала Валаддінівна — асистент кафедри акушерства та гінекології медичного факультету, ДВН3 «Ужгородський національний університет», Ужгород, Україна. ORCID ID: 00000003-0113-8995

Маляр Василь Андрійович — доктор медичних наук, професор, завідувач кафедри акушерства та гінекології медичного факультету, ДВНЗ «Ужгородський національний університет», Ужгород, Україна. ORCID ID: 0000-0001-9950-5014

Маляр Віталій Васильович — доктор медичних наук, доцент кафедри акушерства та гінекології медичного факультету, ДВНЗ «Ужгородський національний університет», Ужгород, Україна. ORCID ID: 0000-0002-1310-535X

Маляр Володимир Васильович — кандидат медичних наук, доцент кафедри акушерства та гінекології медичного факультету, ДВНЗ «Ужгородський національний університет», Ужгород, Україна. ORCID ID: 0000-0003-0350-3255

Адреса для кореспонденції:

Ібадова Тунзала Валаддінівна

tunzala.ibadova@uzhnu.edu.ua
3. Казимирко В.К., Іваницька Л.М., Дубкова А.Г. та ін. (2013) Труднощі діагностики недиференційованої дисплазії сполучної тканини у практиці лікаря-ревматолога. Укр. ревматол. журн., 53(3): 96-100.

4. Маркін Л.Б., Прокіп У.Е. (2014) Функціональна істміко-цервікальна недостатність як прояв недиференційованої дисплазії сполучної тканини. 36. наук. праць Асоціації акушерів-гінекологів України, 1-2: 231.

5. Vink J., Feltovich H. (2016) Cervical etiology of spontaneous preterm birth. Semin. Fetal. Neonatal. Med., 21(2): 106-112. D0I: 10. 1016/j. siny. 2015. 12. 009.

6. Kaufman K.P., Eudy A.M., Harris N. et al.(2021) Pregnancy Outcomes in Undifferentiated Connective Tissue Disease Compared to SLE. www.practiceupdate.com/content/pregnancy-outcomes-inwomen-with-undifferentiated-connective-tissue-disease-compared-with-sle/118253.

7. Castellino G., Capucci R., Bernardi S. et al. (2011) Pregnancy in patients with undifferentiated connective tissue disease: a prospectivecase-controlstudy. Lupus, 20(12): 1305-1311. doi:10. 1177/0961203311409610

8. Российское научное медицинское общество терапевтов (РНм0Т) (2017) Клинические рекомендации «Дисплазии соединительной ткани».

\section{Evaluation of the detection of phenotypic markers of undifferentiated connective tissue dysplasia in women at risk of preterm birth}

\section{T.V. Ibadova, V.V. Maliar, V.A. Maliar, Vol.V. Maliar}

SHEl «Uzhhorod national university», Uzhhgorod, Ukraine

Abstract. Premature birth, especially in the early weeks of pregnancy, is closely linked to perinatal morbidity and mortality. Aim: to assess the detectability and clinical significance of markers of undifferentiated connective tissue dysplasia in pregnant women at risk of preterm birth. Materials and methods. A clinical analysis of phenotypic signs of undifferentiated connective tissue dysplasia in 270 pregnant women with one baby at risk of preterm birth, which were divided into two representative groups: 1st ( $n=112$, main group) with phenotypic signs of undifferentiated connective tissue dysplasia and 2nd ( $n=158$, control group) without phenotypic signs. Results. Among the phenotypic signs of undifferentiated connective tissue dysplasia in pregnant women at the risk of premature birth, the most common were: asthenic body structure (38.4\%), joint hypermobility (33.9\%), myopia (31.3\%). Stigmas of dysembryogenesis were revealed: various anomalies of the skeleton, musculoskeletal system, teeth. There was also a decrease in body mass index, indicators of the ratio of the wrist circumference to the length of the II finger, arm span to growth, heavy menstruation. $86.6 \%$ of patients showed meteorological dependence and subjective signs of respiratory syndrome. Conclusion. The obtained results allow to confirm that pregnant women with signs of undifferentiated connective tissue dysplasia are in the group of high risk of premature birth with the development of hemorrhagic complications.

Key words: premature birth, undifferentiated connective tissue dysplasia, phenotypic signs.

Information about authors:

Ibadova Tunzala V. - MD, assistant professor of the department of obstetrics and gynecology of medical faculty, SHEl «Uzhhgorod national university», Uzhhgorod, Ukraine. ORCID ID: 0000-0003-0113-8995

Maliar Vasyl A. - MD, PhD, DSc, Professor, head of the department of obstetrics and gynecology of medical faculty, SHEl «Uzhhgorod national university», Uzhhgorod, Ukraine. ORCID ID: 0000-0001-9950-5014

Maliar Vitaly V. - MD, PhD, DSc, associate professor of the department of obstetrics and gynecology of medical faculty, SHEl «Uzhhgorod national university», Uzhhgorod, Ukraine. ORCID ID: 0000-0002-1310-535X

Maliar Volodymyr V. - MD, PhD, associate professor of the department of obstetrics and gynecology of medical faculty, SHEl «Uzhhgorod national university», Uzhhgorod, Ukraine. ORCID ID: 0000-0003-0350-3255

Address for correspondence:

Tunzala Ibadova

tunzala.ibadova@uzhnu.edu.ua 